\title{
Russian Proposals on the Polar Code: Contributing to Common Rules or Furthering State Interests?
}

\author{
Dorottya Bognar*, \\ PhD Candidate, Department of Sociology, Political Science and Community Planning, \\ Faculty of Humanities, Social Sciences and Education, UiT- The Arctic University of \\ Norway, Tromsø, Norway
}

\begin{abstract}
The mandatory Polar Code was finally adopted by the International Maritime Organization (IMO) in May 2015. The present article examines the role and contribution of the Russian Federation in the decision-making process of the Polar Code through its proposals, in the form of submissions, statements, and oral interventions. The purpose of these proposals is investigated with respect to the safety and environmental protection goals of the IMO and Russian interests in the Arctic, by looking at the reasoning used by Russia in its proposals. The major issue areas represented in the Russian proposals include, among others, the role of coastal State legislation, environmental regulations, and icebreaker assistance; however, the majority of these do not contribute to the IMO's goals of creating globally uniform standards for maritime safety and protecting the marine environment. The Russian proposals served State interests through misrepresentation and reference to Russia's experience in Arctic shipping. While the latter frames Russia as a leading user of Arctic waters, the role that Russia played in the Polar Code negotiations indicates that Russia has more than shipping interests to protect in the Arctic.
\end{abstract}

Keywords: Arctic shipping; International Maritime Organization; decision-making; law of the sea; Northern Sea Route

Responsible Editor: Tore Henriksen, Professor, Director K.G. Jebsen Centre for the Law of the Sea, Faculty of Law, University of Tromsø - The Arctic University of Norway.

Received: March 2016; Accepted: June 2016; Published: November 2016

\section{Introduction}

The International Code for Ships Operating in Polar Waters (Polar Code) was adopted by the International Maritime Organization (IMO) in November 2014 and May $2015,{ }^{1}$ after years of negotiations. Once it comes into force through amendments to the

${ }^{\star}$ Correspondence to: Dorottya Bognar, Department of Sociology, Political Science and Community Planning, Faculty of Humanities, Social Sciences and Education, UiT - The Arctic University of Norway, PB 6050 Langnes, 9037 Tromsø, Norway. Email: dorottya.bognar@uit.no 


\section{Bognar}

SOLAS $^{2}$ and MARPOL ${ }^{3}$ Conventions, ${ }^{4}$ this new instrument will regulate ship safety and pollution prevention in polar waters. While the Polar Code covers both the Arctic and the Antarctic waters, the present article deals specifically with one Arctic State, the Russian Federation, and its contribution to the negotiation process that resulted in the Polar Code.

Russia is an important player in the Arctic from many perspectives. It has the longest coastline facing the Arctic; the largest Arctic population of all the Arctic States; and a proud reputation, history, and identity connected to the Arctic. ${ }^{5}$ Furthermore, because of the resource wealth of its Arctic Zone,${ }^{6}$ comprising hydrocarbons, timber, minerals, as well as fish, Russia also has important industries located in the area, providing a significant percentage of its GDP and export. ${ }^{7}$ With its long Arctic coastline, Russia also has considerable experience in Arctic shipping. While shipping activity in the Russian Arctic is mainly connected to resource extraction in the region and supply routes to remote communities, part of the current Russian Arctic policy is to encourage the use of the waters off Russia's Arctic coast, the Northern Sea Route (NSR), ${ }^{8}$ for international transit shipping. ${ }^{9}$ Much of the shipping activity in Russian waters is supported by different services, such as icebreaker assistance and pilotage. To make shipping through the NSR easier, new legislation was enacted with regard to the NSR in 2012 and $2013 .^{10}$

The main question this article seeks to answer is how Russia's role and contribution to the Polar Code may be characterised. In order to answer this question, the following sub-questions are raised: 1) Did Russia have a prominent role in the negotiation of the Polar Code? and 2) Looking at the content of its proposals, did Russia utilise its experience in Arctic shipping to further the IMO's goals or its own interests? Section 2 of this article introduces the material on which the research has been based. Section 3 examines the first sub-question raised above, with the hypothesis that Russia's size and stakes in the Arctic made it one of the most interested players in the Polar Code negotiations. Section 4 deals with the content of selected Russian proposals, statements, and interventions, in light of the second sub-question. First, I introduce deliberative theory's distinction between arguing and bargaining to help the analysis, and define the IMO's goals in the context of the Polar Code. The hypothesis made is that, while Russia has furthered its own narrow self-interests in the polar region, it has also been interested in enhancing safety and environmental protection through the new Polar Code, especially since the waters north of Russia are expected to open for ship traffic first. Thus, I will consider which Russian interests were promoted through the Russian proposals and how these were furthered, in order to determine whether the Russian proposals served the IMO's goals or particular State interests. Finally, building on the previous analyses, Section 5 discusses what Russia's participation in the Polar Code negotiations can tell us about what kind of Arctic actor Russia is.

\section{Research material}

During the decision-making process of the IMO, its members and observers submit proposals that are discussed in the different Committees, Sub-Committees, working 
groups, and correspondence groups. Below, analysis is made of Russia's proposals to the IMO's Maritime Safety Committee (MSC) and Marine Environment Protection Committee (MEPC), as well as to the Sub-Committee on Ship Design and Equipment (DE) and its successor, the Sub-Committee on Ship Design and Construction (SDC), where the more detailed work on the Polar Code took place. ${ }^{11}$ Moreover, statements and interventions found in the reports of the Committees and the two Sub-Committees are covered. Statements and interventions serve to highlight States' opinions that were deemed important enough to record in writing.

The documents analysed are those to which it is possible to gain public access via the IMO's database, IMODOCS. ${ }^{12}$ While a great number of decisions were made in the setting of the Committees and Sub-Committees, many others were made in intersessional and correspondence groups among those delegations most interested in polar shipping. While the lack of available documents from these fora imposes limitations on the present research, the volume of documents available - more than 250 in number - compensates for this. This material was further supplemented by interviews conducted with selected delegates to the IMO bodies involved and audio records of the plenary sessions of the Committees and Sub-Committees. ${ }^{13}$

\section{Russia's engagement in the Polar Code process}

Altogether, there are 15 Russian submissions recorded in the IMO's database in the Polar Code. Moreover, there are three statements and four interventions included in the reports of the Committees and Sub-Committees. In addition to these, a Russian proposal or viewpoint is referenced three times in other delegations' submissions: twice by Norway as chair of the intersessional and working groups, ${ }^{14}$ and once by Canada. ${ }^{15}$

These numbers have to be put into perspective. Of the five Arctic coastal States, Canada, Norway, and the United States submitted significantly more documents than Russia: 34, 28, and 22, respectively. ${ }^{16}$ The number of Russian proposals is comparable to those made by Finland and Denmark, with 14 and 12 proposals, respectively.

In addition to the number of submissions, there are a few other indicators that show how engaged Russia was in the Polar Code process. Firstly, as indicated above, there were three statements and four interventions recorded from Russia, more than any other Arctic State. That Russia's separate opinion was recorded indicates two things: that Russia had a strong opinion on the matter at hand and that Russia's opinion differed from the other States that spoke on the issue.

Second, proposals submitted to the IMO's Committees and Sub-Committees are often co-sponsored, with two or more members or observers giving their name to the same proposal. This way, multiple participants can show their support for the proposal. In the case of the Polar Code negotiations, the other Arctic States had a significant number of proposals co-sponsored by one another and by other, non-Arctic States, showing an inclination to cooperate. Contrary to this, Russia did not co-sponsor any proposals. Thus, the documents show a certain degree of isolation in Russia's participation in the Polar Code process. This applies to proposals before and after the outbreak of the Ukrainian crisis in 2014. The cooling of relations between 


\section{Bognar}

Russia and the West does not appear to have had an effect on this aspect of Russian participation.

Third, as will be discussed below, many of the Russian proposals are responses to previous submissions and decisions. In this sense, the Russian proposals are reactive in nature, not proactive. Thus, Russia does not appear to be driving force in the decision-making process, shaping the discussion. Rather, its submissions should be seen as reactions to previous decisions and other members' ideas.

Therefore, based on its submissions, statements, and interventions, Russia does not fulfil the expectation that it would play a prominent, leading role in the Polar Code negotiations. The factors above point to a surprising lack of prominence on Russia's part when compared to, first and foremost, the rest of the Arctic coastal States. It is less surprising that Russia was more engaged than the remaining three Arctic States that make up the so-called Arctic Eight, Finland, Iceland, and Sweden, considering that these do not border on the marine Arctic.

\section{Russian submissions in light of the IMO's goals}

\subsection{Arguing and bargaining in deliberative theory}

In order to provide a framework to analyse Russian submissions about the Polar Code, I will first briefly introduce deliberative theory. Deliberative theory differentiates between different forms of decision-making with distinct motives behind them. As such, the theory will help determine where Russian priorities lay in the Polar Code negotiations.

Central to deliberative theory is deliberation, or arguing, as a decision-making mode. Deliberation is the exchange of reasoned arguments based on the communication of factual or normative assertions which claim to be valid. ${ }^{17}$ Validity here is based on the truth and impartiality as well as the consistency of the arguments. ${ }^{18}$ However, deliberation is not the only form of decision-making; it can be contrasted with negotiation, or bargaining. ${ }^{19}$ As opposed to impartial arguments, bargaining involves demands which claim credibility based on material resources that back up threats, promises, and exit-options. ${ }^{20}$

What is more important to our discussion here is the contrast between the motives behind arguing and bargaining. Deliberation relies on the power of the convincing argument and, therefore, the main motive is disinterested and dispassionate reason. ${ }^{21}$ Meanwhile, the main feature of bargaining is a conflict of interests. ${ }^{22}$ The exchange of reasoned, dispassionate arguments leads deliberation towards a common good that can be found in consensus, whereas the outcome of bargaining should be imagined as dividing a finite pie and, thus, can only result in a compromise. ${ }^{23}$

It has been highlighted that social norms stop States from openly reasoning in terms of their own self-interest. This can lead to misrepresentation: presenting oneself as not being influenced by interest, cloaking one's message in reasoned arguments. ${ }^{24}$ Here self-interested motives are disguised as impartial arguments; thus, arguments are used strategically. ${ }^{25}$ One particular mode of misrepresentation is to disguise a threat as a 
warning. ${ }^{26}$ While such misrepresentation complicates the task of identifying reasoned arguments, it is a good starting point to differentiate between what is a genuinely impartial argument and what is an interested demand.

\subsection{Arguing and bargaining in the context of polar shipping}

How does the above discussion relate to Russia and the IMO's goals with the Polar Code? The exchange of reasoned arguments in deliberation moves the discussion towards a common good, the aim of the deliberation. ${ }^{27}$ This can be linked to what the IMO aimed to achieve with the Polar Code.

In general terms, the IMO, as a specialised organ of the United Nations for international merchant shipping, works to benefit the international community at large. The IMO is also considered the competent international organisation referred to in various articles of the United Nations Convention on the Law of the Sea (LOSC) that exercises quasi-legislative functions with regard to globally uniform minimum standards. ${ }^{28}$ Indeed, one of the functions of the IMO as laid down in the convention that established it, the 1948 Convention on the IMO, ${ }^{29}$ is 'the drafting of conventions, agreements, or other suitable instruments', ${ }^{30}$ with the goal of creating standards for shipping that are globally uniform and are applied in a uniform manner. ${ }^{31}$

However, it has been argued that the flexibility of the Polar Code, especially its safety part, can be problematic for the creation of a uniform set of rules. ${ }^{32}$ A further critique often heard is that the IMO's outcomes represent the lowest common denominator among its global membership. Contrary to these critiques, the position taken in this article is that even 'watered down' standards are better than competing and conflicting standards that divide the international community, or no standards at all. Furthermore, flexibility is beneficial in an area where shipping is in its infancy and where novel approaches might be called for.

While the creation of globally uniform standards is an important element of the IMO's goal, such a definition would not account for the content or the issues covered by said standards. Therefore it is proposed here that the creation of a set of globally uniform standards should rather be seen as an umbrella encompassing other goals of the IMO. To find out what constitutes the substance of the IMO's goals, we can turn again to the Convention on the IMO. Article 1 of this convention lists the purposes of the IMO, including:

to encourage and facilitate the general adoption of the highest practicable standards in matters concerning the maritime safety, efficiency of navigation and prevention and control of marine pollution from ships ... ${ }^{33}$

These goals are repeated and thus reinforced in the IMO's mission statement:

The mission of the International Maritime Organization (IMO) as a United Nations specialized agency is to promote safe, secure, environmentally sound, efficient and sustainable shipping through cooperation. This will be accomplished by adopting the highest practicable standards of maritime safety and security, efficiency of navigation and prevention and control of pollution from ships ... ${ }^{34}$ 


\section{Bognar}

Turning specifically to polar shipping and how the IMO's general goals translate into the polar setting, the submissions proposing the creation of a mandatory Polar Code emphasise the regulatory gap in the area, and highlight that

Establishing a mandatory set of requirements for ships operating in Polar Regions will enhance the safety of life and protection of the marine environment in these remote areas. ${ }^{35}$

This is reiterated in the Preamble and the Introduction of the Polar Code. While the text of the Preamble can be seen more as embodying the spirit of the instrument than a legal obligation, the Introduction is legally binding both through SOLAS and MARPOL. Therefore, I use the latter to signify the substance of the IMO's goals with regard to the Polar Code. The Introduction states expressly:

The goal of this Code is to provide for safe ship operation and the protection of the polar environment by assessing risks present in polar waters and not adequately mitigated by other instruments of the Organization. ${ }^{36}$

Thus, in the following discussion, reference to IMO's goals means the creation of uniform standards to achieve the double aims of ship safety and protection of the polar environment. ${ }^{37}$

Russia is a coastal State with an especially long and remote coastline, which makes environmental clean-up extremely difficult. Furthermore, Russia's activities in the region, as well as vessels in transit, necessitate maritime safety. Therefore, the goals of the IMO and the Polar Code can be said to serve Russia's interest as well. However, as the largest Arctic State, Russian interests in the region are diverse. Some of these interests may differ from the goals the IMO aims to achieve with the Polar Code, and can be linked to the motive of self-interest of the bargaining decisionmaking mode. Therefore, the IMO's goals, the common good towards which the IMO has worked, can be explained in contrast to what it is not.

Much has been written about Russia's strategic interests and policies regarding the Arctic. ${ }^{38}$ Here, I will only introduce those interests which are important to this discussion on Russian proposals about the Polar Code. First of all, in the domain of international law, the legal status of some of the waters off of Russia's northern coast, and thus the extent of Russia's coastal State sovereignty and jurisdiction there, is contested. Russia relies heavily on the Arctic exception in LOSC, article 234, and its coastal State right on that basis to adopt and enforce regulations along the NSR without approval from the IMO. ${ }^{39}$ This right and practice have been contested by the United States. It has been suggested that Russia would seek to gain international legal recognition for these regulations through the Polar Code, or introduce similar requirements to its own domestic rules, in case art. 234 becomes more controversial in the future. ${ }^{40}$ Russia is also keen to use art. 234 and the perceived rights therein to exert control over shipping for security reasons in an area that it sees as vulnerable and where its strategic nuclear weapons are based.

On a more practical level, Russia has been keen to encourage international transit shipping through the NSR, hoping for economic gains from increased activity. 
Yet, funds for necessary investments in infrastructure, including port facilities and icebreakers, have been slow, creating delays. ${ }^{41}$ New international regulations leading to further costs would not be helpful for Russian shipping aspirations. Beyond the prospects of increased international shipping, domestic Russian activities in the region include, notably, destinational shipping of natural resources and supplies to regional settlements, as well as fishing. The fishing industry is especially important in the Russian Far East where it provides for much needed employment, despite the fact that it is in dire need of a new, seaworthy fleet. ${ }^{42}$ It is also worth noting that Russia has been carrying out scientific research as well as surveying related to hydrocarbons and its extended continental shelf. Thus, while Russia is an Arctic coastal State, it also has significant interests related to shipping and navigation. ${ }^{43}$ In practice, Russia's coastal State interests are often intertwined with its flag State interests: to be able to enjoy its coastal State rights as regards fisheries and hydrocarbon resources Russia relies on many Russian-flagged vessels, while to keep control over transit along the NSR, Russian icebreakers are used. Russia regulates fishing, survey vessels, and icebreakers not only in its flag State capacity, but also in order to satisfy its interests as a coastal State.

\subsection{Russian proposals}

Having defined the IMO's goal to create globally uniform minimum standards to achieve safe ship operations in polar waters and to protect the polar environment, as well as having established separate Russian interests in the Arctic, it is now possible to start considering specific Russian submissions about the Polar Code. Did these submissions contribute to the creation of uniform standards for maritime safety and environmental protection, or did they promote other Russian interests?

The Russian proposals, statements, and interventions that are subject to this analysis were concerned with four broad topics: 1) the role of the coastal State's national legislation; 2) environmental regulations, especially with a focus on discharges of oil and oily mixtures; 3) the geographical scope of the Polar Code; and 4) systems for determining limitations for ship operation in ice, including POLARIS. ${ }^{44}$ Furthermore, it should be mentioned that a fifth issue espoused by Russia appears in two submissions made by Norway, namely icebreaker assistance. In the following, each of these five topics will be briefly introduced and analysed.

\subsubsection{The role of the coastal State's national legislation}

Two Russian proposals took up the controversial issue of national regulations, with express reference to LOSC art. $234 .{ }^{45}$ The first of these proposals, submitted to the 55th session of the DE Sub-Committee, cites the above-mentioned article excessively, and makes reference to Russian legislation on navigation along the NSR, professedly adopted in accordance with that article. This document leaves no room to the imagination as to what the Russian Federation is aiming to achieve here. The proposal endorses a principle previously included in a Canadian draft of the Polar Code, namely 'the principle of priority of national regulations over the Code's 
requirements', ${ }^{46}$ and proposes its re-introduction to the Preamble of the Polar Code with the following text:

The Code is not intended to infringe on national systems of shipping control until a harmonized system is in place; in addition to applicable sections of the Code, port, Treaty and coastal States may retain local navigation rules and regulations for certain routes and waterways under their jurisdiction taking into account local conditions, infrastructure and procedures. ${ }^{47}$

The second proposal only contains one sentence on this topic, stating that 'limitations for navigation in ice conditions are imposed by ... national rules adopted by the coastal State empowered accordingly by article $234{ }^{48}$ This subtle reference is no doubt due to the concerns raised by the United States and others during DE $55 .^{49}$

While no further Russian proposals were submitted on the issue of national regulations after DE 56's decision to focus solely on technical matters, not jurisdictional issues, ${ }^{50}$ one Canadian proposal includes a brief reference to Russia's support of Canada's position on a savings clause, clarifying the relationship between the Polar Code and other international agreements and international law, notably LOSC. $^{51}$

It should be relatively easy to see that these proposals were meant to further Russia's self-interests, rather than the IMO's goal. ${ }^{52}$ First, on the issue of Russian coastal State control over shipping along the NSR, it is in Russia's interest to uphold its regulations. Thus, when Russia gave its support to the 'principle of priority of national regulations over the Code's requirements' and suggested the inclusion of text in the Polar Code stating that the 'Code is not intended to infringe on national systems of shipping control', 53 this is intended to serve as international legal recognition of Russia's interpretation of LOSC art. 234.

Second, giving priority to national regulations over the Polar Code is directly opposite to what we have established as the IMO's goal towards which the Polar Code negotiations worked, namely uniform standards for safe ship operations and protection of the polar environment. While uniform standards might be achieved, providing expressed priority to national regulation over these standards undermines the intention to apply them uniformly. Therefore, these Russian proposals are inconsistent with the goal of uniform application.

While the above arguments are enough to categorise this topic as being motivated by self-interest, we still need to look at what reasoning the submissions provided in support of Russia's proposals. DE 55/12/23, which suggests the inclusion of the principle of priority, relies heavily on the coastal States' rights under LOSC art. 234, while also referring to the 'necessary skills and knowledge on ensuring the safety of navigation' 54 possessed by the coastal States' maritime authorities. DE 56/10/14 only contains one sentence referring to the coastal State's national rules, which again highlights that these States are 'empowered accordingly by article 234'. 55 The inclusion of this sentence in a submission otherwise denoted to ship categories related 
to ice-strengthening and ice thickness gives the impression that limitations imposed by the national regulations of coastal States contribute to increasing ship safety.

Both of these Russian proposals include reference to the safety of ship operations. Yet, both of them also emphasise the importance of LOSC art. 234, in which Russia's contested claims to jurisdiction are grounded. While the former reasoning can be taken as pointing towards one substantive element of the IMO's goal, the latter casts doubt on this as the invocation of LOSC art. 234 serves to support the acknowledgement of coastal State jurisdiction, one of Russia's interests.

\subsubsection{Environmental regulations relating to the discharge of oil and oily mixtures}

While there are two Russian statements recorded in the report of DE 56 which are more general in nature and concern many different types of vessel-source pollution, ranging from grey water through heavy fuel oil to SOx and NOx emissions, ${ }^{56}$ the bulk of Russian proposals related to the environment deal with the discharge of oil and oily mixtures.

The first proposal that mentions the discharge of oil and oily mixtures was submitted to DE $57 .{ }^{57}$ It is similarly broad in nature to the two Russian statements to DE 56. Incidentally, this is the only proposal on this topic submitted before a decision was made two months later at MEPC 65 to prohibit any discharge of oil and oily mixtures from any ships in polar waters. ${ }^{58}$

Starting with the proposal made to SDC 1, Russian submissions addressing the discharge of oil and oily mixtures from machinery spaces seem to continuously change the scope of the Russian proposal, aiming at overturning the decision made previously. ${ }^{59}$ This applies to both the kind of vessels exempted and the conditions and circumstances under which discharges would be permitted. The range of vessels in the Russian proposals narrows over time from all ships in the first submission, to ships with structural features preventing compliance in a later submission, and finally to ships operating in polar waters for longer periods of time. The proposed conditions change from a general exception for these ships in the Arctic, ${ }^{60}$ to an exemption at the Maritime Administration's discretion, and then to a 5-year exemption period.

The discussion of environmental regulation related to the discharge of oil and oily mixtures seems to be directly connected to the environmental protection part of IMO's goal. However, the Russian proposals urge less strict pollution prevention rules than that agreed upon by MEPC. On the face of it, therefore, it seems that these proposals are counter-productive to enhanced protection.

Furthermore, the fact that Russian proposals made after the MEPC's decision have continuously changed the scope suggests that these proposals were part of a give-and-take on Russia's part, in other words: bargaining. The line of proposals starts with document SDC 1/3/18, a short document containing just one justification: that the complete ban would be 'extremely difficult to adhere to, given the significant length of ships' voyages'. ${ }^{61}$ The general lack of justification apparent here is more of an indication of demand to agree with the Russian position than an attempt at deliberation to convince the other States through reasoned arguments. 


\section{Bognar}

A hidden demand can be observed in the audio records where Russia states in relation to $\operatorname{SDC} 1 / 3 / 18$ :

we understand that the Sub-Committee may decide to go along with the MEPC recommendation, but we'd like to inform you that we will actually be coming forth with a similar proposal at the MEPC meeting. ${ }^{62}$

Another interesting feature of this submission is its espousal of conditions applicable in MARPOL special areas and the requirement on oil filtering equipment with alarm and automatic stopping arrangements. This is notable as Russia was previously sceptical both of establishing such special areas in the Arctic, as well as using the related requirements on oil filtering equipment. ${ }^{63}$ This inconsistency in Russia's stance can be evidential of self-interested bargaining.

Further submissions by Russia included more extensive reasoning to justify the Russian proposals, often repeating the same justifications verbatim. Among these are references to scientific research, highlighting that possible discharges in the region were unlikely to pose an environmental threat, and suggesting that calls for a complete ban were not well substantiated. The latter is not explained in further detail, which leaves its truth-claim unverifiable and, thus, its convincing power questionable. It is, therefore, doubtful if this reasoning can be taken as an argument meant to be part of deliberation. Similarly, while some of the scientific research referred to by the Russian proposals are cited, meaning their truth-claim can be established, other passages in the submissions only mention research results in general. The lack of verifiability and the inconsistency of citation within the same proposals suggest the strategic use of arguments said to be based on research.

The proposals also retain the reasoning from SDC $1 / 3 / 18$, and it is further specified that the vessels likely to be negatively affected by a complete ban are ships operating in the Arctic for months without calling at ports, such as 'icebreakers, hydrographic survey ships and research vessels', ${ }^{64}$ as well as ships engaged in transit voyages. Thus, complying with the ban would be potentially detrimental to Russian interests related to maintaining its ability to provide icebreaker support. It could also prove discouraging to transit shipping. Furthermore, warnings are also made in these proposals that a complete ban would adversely affect shipping, ${ }^{65}$ and possibly lead to illegal discharges.

Finally, reference is made to Russia's vast experience and the attention it pays to maritime safety and environment protection. These claims can serve to provide legitimacy to the repeated Russian demand to overturn the complete ban, and the justifications brought forth to this end.

Related to the discharges of oil and oily mixtures in the Arctic, Russia also submitted a proposal on reception facilities. ${ }^{66}$ This submission highlights the view that the question of adequate reception facilities in the Arctic should not be regulated by the Polar Code - contrary to the proposal of many flag States and shipping organisations contained in document SDC $1 / 3 / 1 .^{67}$

It is notable that in MEPC 67/9/4 Russia reasons that there is not a need for reception facilities at each Arctic port, because of the limited nature of Arctic shipping. This seems to be an attempt to argue with convincing, verifiable arguments. Indeed, a study 
by the reputable Det Norske Veritas (DNV) under the aegis of the Arctic Council's Working Group on the Protection of the Arctic Marine Environment (PAME) is cited in support of the Russian proposal. However, at the same time, reference is made to the extremely burdensome nature of the requirement on reception facilities and the considerable maintenance costs of such facilities, suggesting that including a requirement to provide for reception facilities at each Arctic port would further add to the costs and difficulties Russia is likely to experience in developing its Arctic infrastructure. During debate on this issue, Russia highlighted that it was not the cosponsors of SDC $1 / 3 / 1$ that would have to bear the costs of the proposed reception facilities, and suggested, using non-diplomatic language, that it could agree to the construction of such facilities if the co-sponsors were to fund it. ${ }^{68}$

On the whole, it seems that during the discussion of environmental regulations relating to the discharge of oil and oily mixtures, Russia kept two of its interests in mind. On the one hand, it tried to reduce the costs and difficulties for the shipping industry by exempting some of the Russian vessels, as well as foreign vessels in transit, from complying with the complete ban on oil and oily mixtures discharges, thus, promoting Russian shipping activities in the Arctic, as well as transit shipping. On the other hand, Russia sought to limit its own costs as a port State related to infrastructure development, specifically in relation to the construction of reception facilities in each Arctic port.

\subsubsection{Icebreaker assistance}

Russia briefly mentioned icebreaker escorts in a proposal to DE $54,{ }^{69}$ and made an intervention at $\mathrm{DE} 55$, observing the lack of consideration given to the issue. ${ }^{70}$ These early Russian proposals are limited to a discussion of the need for the inclusion of rules on such escorts. ${ }^{71}$ Significantly, the intervention at DE 55 also warns that

safety of navigation in the Arctic regions adjoining the Russian Federation could not be guaranteed without the aid of icebreakers, except for one or two months of the year.$^{72}$

Since this warning is included together with the observation that the issue of icebreaker assistance had not previously been considered sufficiently with regard to Russian submission DE 54/13/10, this can be taken as a hidden demand for more discussion. Common to these documents are references to improved safety through the use of icebreaker assistance and extended navigational seasons. It is true that icebreaker assistance is often necessary to ensure safe passage in ice-covered waters and, thus, the inclusion of regulation related to icebreakers can further the IMO's goal. However, the reference to safety can also be seen as indirectly providing legitimacy to a Russian demand for further discussion on the issue, especially when read together with the reference to extended navigational seasons. Again, the Russian interest to open up the NSR to international transit shipping is noteworthy, as the use of the NSR for extended navigational seasons was expected to generate more income to the Russian authorities through various fees. At the time these documents were submitted, the scope of the Russian Federation's requirements for icebreaker 


\section{Bognar}

escorts along the NSR was much wider than in the new 2013 NSR Rules. This can be linked to the Russian statement that all ships are in need of icebreaker support. ${ }^{73}$

This brings us to a Russian proposal made to an intersessional working group on the Polar Code, which is referred to in two Norwegian submissions, and the content of which was included in the recommendatory part of the final version of the Polar Code. The original submission is not publicly available and, therefore, it is not possible to assess any reasoning given by Russia with regard to the proposal, which calls for setting uniform procedures for icebreaker assistance for the maintenance of safety in icebreaker operations. As such the proposal would seem to contribute to the IMO's safety goals. However, a noteworthy aspect of the proposal is its close similarity to paragraphs 26-30 of the Russian Rules of navigation in the water area of the Northern Sea Route, dated 17 January 2013, a few months before the intersessional working group which took place from 30 September to 4 October the same year. The report of this meeting is the first document that mentions the Russian proposal on icebreakers. Thus, the inclusion of these regulations appears to further both the IMO's goal and Russia's interest to shape the Polar Code to its own needs.

\subsubsection{The geographical scope of the Polar Code}

While the Polar Code uses the same geographical area of application as regards Russian waters as the 2002 and 2009 IMO Guidelines, ${ }^{74}$ the Russian Federation attempted to modify this at later meetings. First, at SDC 1, Russia's statement is recorded to the effect that the geographical scope of the Polar Code should exclude the northern part of the Bering Sea. ${ }^{75}$ This was followed by a proposal and intervention at MSC $93 .^{76}$

The reasoning used by Russia to justify changing the geographical scope of application of the Polar Code was based on hazards specific to the polar region as well as on the 'available experience of shipping in polar areas'. ${ }^{77}$ The hazards include the characteristics of the Bering Sea, which make it, in Russia's opinion, a freezing sea that should not be covered by the Polar Code, rather than an Arctic sea. Furthermore, the lack of polar day and polar night, no high latitude zone and the availability of search and rescue services were also mentioned. These reasons seem to be unbiased and their truth-claims should be easily verifiable.

What is more interesting is that this Russian proposal was made relatively late in the Polar Code process, considering that the geographical boundaries had been used in the preceding discussions. With regard to the definition of Arctic waters, Russia states that

we consider that such a straight transfer of these provisions into a mandatory IMO instrument is not relevant, bearing in mind the importance of the future Code for navigation in Arctic polar waters. ${ }^{78}$

This formulation seems to imply that, for Russia, what makes the difference is whether the IMO instrument is mandatory, not whether operating in the waters in question and the additional hazards present there require new safety or environmental regulations. This is contrary to IMO's aims with the Polar Code. 
Russia also suggests that a change in geographical scope should be justified by the actual practice of polar shipping, which provides a clue of Russia's interest in this matter. Along with ships transiting the Bering Strait, to which the Polar Code would apply anyway, Russia also mentions fishing vessels and fishing support vessels. The submission states that these vessels typically navigate near the ice edge,

thus rendering the application of the Polar Code's requirements in their entirety impractical, and reducing fishing areas to a significant extent. ${ }^{79}$

The Polar Code does not concern the regulation of fishing; therefore, the suggestion that fishing areas would be reduced seems out of place. However, the planned phase2 of the Polar Code will regulate fishing vessels. ${ }^{80}$ Furthermore, MARPOL currently applies to such vessels. ${ }^{81}$ Therefore, the geographical scope of the Polar Code will impact the largely unseaworthy fishing fleet of the Russian Far East, on which many livelihoods depend. ${ }^{82}$

Furthermore, Russia also claims that its own regulations on the NSR treat the northern part of the Bering Sea separately from the NSR and that this approach is vindicated by the lack of negative effects on navigational safety in Russia's 'manyyear experience of shipping along the Northern Sea Route'. ${ }^{83}$ Thus, while the Russian proposals to exclude the northern part of the Bering Sea from the Polar Code also rely on factual claims whose content is verifiable and accordingly can be used as arguments in deliberation, another motive for these proposals is self-interest in the Russian fishing fleet, as well as correspondence of the Polar Code's geographical scope with that of Russia's NSR regulations.

\subsubsection{POLARIS and other systems for determining limitations for ship operation in ice}

To determine the limitations of ship operation in ice and, thus, to make the Polar Code more practically applicable, the International Association of Classification Societies (IACS) developed the POLARIS system based on the contributions of Canada, Finland, Russia and Sweden. Even though Russia did contribute to the work on POLARIS, three of its proposals to MSC 94 served to criticise and discredit the system. ${ }^{84}$

In its attempt to include POLARIS in a separate instrument, outside the Polar Code, Russia highlights detailed technical problems with POLARIS, including the combination of speed and ice thickness, lack of testing, and problems with the Canadian system that POLARIS is mainly based on. The content of these justifications is verifiable and, thus, may be part of deliberation to produce uniform standards for navigational safety.

Yet, in MSC 94/3/22 Russia discusses at length its suggestion that the prescriptive approach to limitations for ship operations, practiced by Russia, should have equal status to methods based on risk assessment, including POLARIS and the Canadian approach. While it serves the common interest of safety to require each system to have sufficient experience before approval, the general proposal that

methods based on risk assessment ... may be recommended for application after some experience of their use is available, ${ }^{85}$ 


\section{Bognar}

also seems to encompass the Canadian system, and would then, in practice, not create equal status for the two approaches.

Furthermore, Russia proposes an amendment to the POLARIS system with Russian ice classes based on prescriptive requirements and Russian shipping experience in the Arctic, since

this step will definitely make the modelling and approaches of POLARIS much more profound and widely applicable especially in the Arctic region along the Northern part of the Russian Federation. ${ }^{86}$

The separate emphasis on Russian waters, together with Russia's insistence on equal status for its own approach to operational limitation, seems to signal that Russia wants to retain its influence over ships off its coast. As a flag state it could require its vessels to use the prescriptive, Russian approach, highlighted by Russia's insistence on the right of the maritime administration to specifically approve the use of novel operational restriction systems. By modifying the POLARIS system to include the Russian approach, Russia would also have indirect influence over foreign-flagged vessels operating in its waters under POLARIS.

Thus, while Russia can be seen to be contributing to navigational safety by pointing out technical problems with POLARIS, ${ }^{87}$ this points in the same direction as Russia's wish to exclude POLARIS from the Polar Code. Both objectives are served by Russia's proposal to develop POLARIS further by amending it with Russian rules, as POLARIS will not be included in the Polar Code as long as it is under amendment.

\subsection{Conclusion: self-interested bargaining or arguing to further the IMO's goals?}

The definition of the IMO's goal as the development of uniform standards to achieve safe ship operation and the protection of the polar environment has two elements to it: the development of globally uniform standards and their content, the safety of ship operations, and/or the protection of the polar environment. Of the five main themes identified and discussed above, it is the issue of icebreaker assistance which comes closest to fulfilling both elements of this definition. The proposal for icebreaker assistance does serve to promote the safety of ship operation in polar waters and aims at uniform rules. Even though it ended up in the recommendatory section of the Polar Code, the original proposal seems to have contained mandatory language. ${ }^{88}$ Without knowledge of the original submission, it is impossible to assess what justifications were used by Russia. However, the correspondence of the proposed text and that of the Russian legislation seems to indicate that, while the proposal contributed to uniform standards for ship safety, it also furthered Russia's self-interest.

In the case of POLARIS, Russia's technical comments as well as its insistence on further testing could be seen to serve maritime safety. It is, however, more questionable whether the Russian proposals contributed to uniform standards. First, as was pointed out, Russia promoted equal status for the two approaches to operation limitation, thus also furthering its own interests. Second, the fact that POLARIS was excluded from the Polar Code, an outcome Russia proposed in its 
submissions, makes it more likely that a uniform operation limitation system will not be reached.

With regard to environmental regulations and the geographical scope of the Polar Code, it is not clear how proposals under either of these areas would contribute to safe ship operations or the protection of the polar environment. In both cases, Russian interests were easily identifiable insofar as reference to them was already included in the proposals. Furthermore, we witness an attempt at bargaining in the series of Russian submissions on the issue of oil and oily mixtures discharges. Finally, the Russian submissions concerning coastal State regulations neither contributed to setting uniform standards, nor did they contribute to further navigational safety or environment protection aims.

\section{Discussion}

Having explored the question in Section 3 as to how prominent a role Russia played in the Polar Code negotiations, as well as in Section 4 as to whether Russia utilised its experience to further the development of uniform rules on safety and environment protection, or to serve its own self-interests, the article now turns to a more general discussion. In the following pages, a couple of conclusions about Russia's participation in the Polar Code process are offered. On the basis of these conclusions, and the findings of the previous section, I examine what can be said about Russia as an Arctic State and about what kind of actor Russia is in the Arctic.

\subsection{Reaction versus proaction}

Most of the Russian topics discussed in this article can be characterised as reactive rather than proactive. The Russian proposal to include the principle of priority of national regulations over the Polar Code can be seen as a result of the same principle having been omitted from documents after its initial suggestion by Canada. In the case of the regulation of oil and oily mixture discharges, the Russian proposals were a direct result of MEPC 65's decision to ban all such discharges. The proposal on reception facilities came after a provision was included in square brackets in the draft of the Polar Code regarding the coastal State's obligation to provide adequate reception facilities in all ports in the Arctic. ${ }^{89}$ Discussion on the geographical scope of the Polar Code was opened by Russia even though the definition of Arctic waters had been used in previous sessions. Indeed, one of the reasons cited in MSC 93's report for rejecting the Russian proposal is that the geographical boundaries had already been agreed upon. ${ }^{90}$ Russia's opposition to POLARIS was brought about by the possibility that POLARIS would be incorporated into the Polar Code.

Of these issues, Russia successfully prevented the inclusion of POLARIS and mandatory reception facilities, both of which are areas where decisions had not been reached previously. In the case of geographical scope and discharges, Russia even tried to reopen the debate on issues that had already been agreed upon, thus being counter-productive to the timely adoption of the Polar Code. 


\section{Bognar}

The most proactive of the Russian submissions is its proposal for the regulation of icebreaker assistance. Russia did achieve its inclusion in the Polar Code, albeit in the recommendatory section.

\subsection{Modes of furthering self-interests}

As demonstrated above, most of the Russian proposals were not concerned with contributing to the creation of uniform standards for ship safety and environmental protection. Even those submissions that contained elements of this, for example those on icebreaker assistance and POLARIS, can be linked to Russian State interests. How did Russia go about prioritising its own self-interests?

One of the most important issues for Russia with regard to jurisdiction in the Arctic is the question of domestic coastal State regulation based on LOSC art. 234 and international regulation through the IMO. In relation to this issue, the DE SubCommittee's 56th session seems to be a watershed. At DE 56, as a response to Canadian and Russian proposals touching upon coastal State jurisdiction, it was decided that priority would be given to technical instead of legal issues, which could be discussed at a later point in time. ${ }^{91}$ This decision seems to have led to an observable change in the activity of Russia.

First, the number and composition of the documents submitted by Russia changed. Before the decision of DE 56, Russia submitted four proposals, and five statements and interventions were included in reports. ${ }^{92}$ After DE 56, the number of Russian proposals was eleven, along with just one statement and one intervention. Additionally, it was in this period that Russia submitted its proposal on icebreaker assistance to the intersessional working group. Having taken place in early 2012 , DE 56 was roughly half-way through the development process of the Polar Code, between 2009 and 2015. Thus, the first period of the negotiations featured half as many Russian proposals, while the number of statements and interventions recorded in the final reports shrunk markedly in the second period of the negotiations.

Second, there was also a difference in the content of the submissions before and after DE 56. Prior to DE 56, the Russian documents were mainly concerned with more technical aspects such as icebreaking capability, ice classes, and icebreaker escorting. One of the proposals discussed in relation to coastal State regulations deals largely with such issues. However, proposals submitted after DE 56 dealt with a larger variety of - and more interest-laden - topics.

Interestingly, while the priority of national regulations espoused by Russia does not re-occur in documents submitted after DE 56, Canada made reference to Russia's support for the inclusion of a savings clause into the amendment of the MARPOL Annexes, which made the Polar Code mandatory. ${ }^{93}$ While Canada expressed the belief that the savings clause would make the relationship between the Polar Code and other international agreements and international law, notably LOSC, clear, ${ }^{94}$ in effect the savings clause also serves to safeguard the Arctic coastal States' rights with regard to national legislation under LOSC art. 234. Thus, it seems that, after DE 56, the Russian delegation was more circumvent. On the one hand, its practical proposals supported coastal State interests, often intertwined with flag State interests. 
These proposals included the question of oil and oily mixtures discharges from icebreakers and survey vessels, rules of icebreaker assistance, the geographical scope of the Code as well as operational limitations through POLARIS. On the other hand, insofar as Russia supported the Canadian proposals on savings clauses, Russia's interests relating to coastal State legislation were clad in a language regarding legal clarity, instead of directly relating to the rights enshrined in art. 234. Furthermore, Russian support for these proposals meant support for a possibly wider application and stronger effect for the savings clauses. This is because these savings clauses were proposed for the chapters making the Polar Code mandatory in the parent Conventions, SOLAS and MARPOL, and not in the Code itself as originally envisaged. Being included in SOLAS and MARPOL would make these savings clauses stronger, while also possibly allowing them to influence the interpretation of other provisions of the Conventions not directly related to the Polar Code.

Thus, while the principle of priority of national regulations was dropped by Russia after it was rejected at DE 56, this did not mean that Russia stopped trying to prioritise its own State interests.

\subsection{Russia's experience in Arctic shipping}

A running thread of justification found throughout the documents submitted by Russia is reference to Russia's experience in Arctic shipping. The supposed superiority of this experience is underscored by characterising it as 'vast', 'extensive', 'many-year', and ' 100 year'. 95 Implicit in these references to Russia's experience is the claim that Russia knows better, Russia's proposal is more valid. While Russia does have a long history of shipping off its Arctic coast, it is questionable whether such a justification is relevant to, for example, where the boundaries of the Polar Code's geographical scope should be drawn. Technical areas, such as icebreaking and ice-strengthening, lend themselves better to justification on the grounds of extensive experience in polar shipping. Yet, the small number of Russian proposals submitted during the Polar Code negotiations in general and the even smaller number on the topic of navigational safety, are surprising in light of the eagerness to highlight Russia's vast experience in Arctic shipping apparent in Russia's proposals.

One element of this justification based on Russian experience is reference to the suitability of pre-existing Russian legislation on shipping along the NSR, such as when Russia makes a case for excluding the northern part of the Bering Sea from the geographical scope of the Polar Code. The adequacy of the Russian legislation is again based on the Russian polar shipping experience and, thus, should serve as a leading guide in the formulation of the Polar Code. While the justification for Russia's proposal on icebreaker assistance is not publicly available, the same rationale appears to shine through this proposal, in that it mirrors Russian NSR regulations regarding icebreaker assistance.

An interesting aspect of the emphasis on Russian polar shipping experience is that it frames the Russian Federation not so much as a coastal State, but more as the State with the most extensive use of the Arctic waters, a maritime Arctic State. Thus, while Russia is undoubtedly an Arctic coastal State with interests related to that, the 


\section{Bognar}

reference to its superior knowledge of polar shipping serves to point out that it also has maritime interests inasmuch as a great deal of its Arctic activities require shipping off its northern coast.

\subsection{Russia, the Arctic actor}

On the basis of the above, there seems to be a discrepancy between Russia's self-image and the reality of its participation in the Polar Code process. Russia's self-image as the main user of Arctic waters with superior knowledge of polar shipping, as well as Russia's extensive reference to this as justification for its proposals, implies that Russia should take a leading position in questions of Arctic shipping. From the stance of Russia, Russia's proposals and views should be given more weight in debates, as Russia has the most relevant knowledge and understanding.

Yet, as has been shown, Russia's partaking in the Polar Code negotiations can be characterised by a reactive approach to the debate, a somewhat isolated position among the Arctic States and inconspicuous activity considering Russia's size and importance in the Arctic and, not least, its self-image. Leadership is, of course, not established by the numbers of proposals submitted. However, analysis of the content of the Russian submissions shows that, rather than demonstrating leadership on a wide array of issues, Russia pragmatically picked issue areas where it saw its own interests affected. It becomes clear then that Russia favours national regulations over uniform international standards and its own interests over the goals of the IMO, that is, the wider international community.

When looking at the Russian interests put forward in its submissions, it is clear that Russia is not just a coastal State, nor just a maritime user State of Arctic waters, but an actor with a wide array of interests in the Arctic. Russia acted in its capacity as a coastal State both with regard to safeguarding national regulations and over the question of reception facilities. ${ }^{96}$ In its attempts to maintain control over shipping along the NSR, Russia acted on its security concerns. It acted in its shipping interest when the question of oil and oily mixture discharges from machinery spaces was debated. Russia acted in its interest relating to fishing when wanting to change the geographical scope of application of the Polar Code. And even though it proposed laxer standards on oil and oily mixture discharges from machinery spaces, Russia did not oppose strict standards on, for example, discharges of noxious liquid substances or untreated sewage. In some cases, therefore, Russia also kept its environmental interests in mind - after all, it has the longest Arctic coastline and clean-up could prove impossible or very costly. Thus, Russia should not be seen as a one-sided actor in the Arctic. Russia has many interests in the region and, in its work on the Polar Code, Russia tried to protect all of these interests, unlike its self-image suggests.

\section{Conclusion}

The analysis of material from the IMO's database shows that the Russian experience in Arctic shipping did not translate into extensive contributions to the development 
of uniform standards for safe ship operation and environment protection in polar areas. First, it has been shown that Russian activity in tabling proposals lagged behind, notably, that of Canada and the United States. Moreover, the majority of the Russian proposals were reactive rather than proactive. Second, the majority of the issue areas and actions Russia espoused did not contribute substantially to navigational safety or protection of the environment, while some of its proposals effectively acted against the aim of creating globally uniform minimum standards. Therefore, Russia's contribution to the Polar Code in general cannot be said to have aided the achievement of the goals which States set out at the onset of the Polar Code negotiations.

Most of the Russian proposals seem to have an underlying motive of self-interest. ${ }^{97}$ These interests include upholding Russia's legal, jurisdictional claims as regards the NSR and control over vessels. Russian interests are also linked to the possibly burdensome and negatively perceived consequences of future implementation of the Polar Code's regulations: financial and economic implications, such as upgrading Russian icebreakers, survey and research vessels, and fishing fleet; discouragement of international transit shipping through the $\mathrm{NSR}^{98}$; and the burden of providing for adequate reception facilities in each Arctic port. Russia furthered these interests in a pragmatic manner in its proposals, showing that it has a holistic identity in the Arctic setting - as opposed to a distinctly coastal State identity or the maritime user identity emphasised by the Russian proposals.

Regulation regarding fishing vessels are set to come up in the planned phase- 2 of the Polar Code, along with other non-SOLAS vessels, such as pleasure crafts and mobile offshore drilling units. It will be interesting to see whether there will be a noticeable change in Russia's approach and participation in the negotiations during phase-2, since it will touch on issues vital to the Russian fishing and offshore hydrocarbon extraction industries. Will Russia continue to further its own interests above the goals set out by the IMO and only pay lip-service to international cooperation in the Arctic? Will Russia continue to be reactive and not share its experience for the benefit of the international community? Or, will Russia live up to its own image as a leading Arctic State with many years of experience in polar shipping?

\section{ACKNOWLEDGEMENTS}

The author would like to thank Prof. Hans-Kristian Hernes, UiT The Arctic University of Tromsø, for his continuous support, as well as Prof. Erik J. Molenaar, Netherlands Institute for Law of the Sea, Utrecht University, and K.G. Jebsen Centre for the Law of the Sea, UiT; and Arild Moe, Senior Research Fellow at Fridtjof Nansen Institute, Lysaker, Norway for their review and comments. This work would not have been possible without the help of an environmental NGO with consultative status at the IMO. This article is part of the project 'Arctic Shipping through Challenging Waters', financed by the Research Council of Norway. 


\section{NOTES}

1. IMO Res. MSC.385(94), adopted on 21 November 2014; and IMO Res. MEPC.264(68), adopted on 15 May 2015.

2. International Convention for the Safety of Life at Sea, London, 1 November 1974.

3. International Convention for the Prevention of Pollution from Ships, as Modified by the Protocol of 1978 Relating Thereto, London, 2 November 1973 and 17 February 1978.

4. The Polar Code will enter into force through the tacit acceptance procedure of SOLAS and MARPOL. The Code contains additional regulations to those previously found in the main IMO Conventions, and complements other IMO regulations.

5. Pavel K. Baev, 'Russia's Arctic Policy. Geopolitics, Mercantilism and Identity-Building', UPI Briefing Paper 73 (2010): 5-7; Marlene Laruelle, Russia's Arctic Strategies and the Future of the Far North (Armonk, NY: M. E. Sharpe, 2014), 24-46.

6. For a definition of the Arctic Zone of the Russian Federation (AZRF), see Russian Federation, Basics of the State Policy of the Russian Federation in the Arctic for the Period till 2020 and for a Further Perspective, 2008. For a discussion of the geographical terminology of the Russian Arctic, see Laruelle, Russia's Arctic Strategies, supra n. 5, 28-33. For an interpretation of the AZRF as a reinvention of the Soviet sector doctrine, see Lincoln E. Flake, 'Forecasting Conflict in the Arctic: The Historical Context of Russia's Security Intentions', The fournal of Slavic Military Studies 28, no. 1 (2015): 94-6.

7. Laruelle, Russia's Arctic Strategies, supra n. 5, 135-67.

8. The NSR as a concept originates from Russian legislation where it is defined as 'the historically emerged national transportation route of the Russian Federation', see Russian Federation, Federal Law on Amendments to Specific Legislative Acts of the Russian Federation Related to Governmental Regulation of Merchant Shipping in the Water Area of the Northern Sea Route, signed 28 July 2012, published 30 July 2012. The NSR does not entirely overlap with the Northeast Passage, as the former spans from Novaya Zemlya to the Bering Strait.

9. Russian Federation, Basic Strategy, supra n. 6. In spite of, and maybe because of, the fall in traffic along the NSR in recent years, plans are being drawn up to make shipping along the NSR more viable, see Trude Pettersen, 'Medvedev Orders Plan to Increase Northern Sea Route Capacity', Barents Observer, 10 June 2015, http://barentsobserver.com/en/arctic/2015/06/ medvedev-orders-plan-increase-northern-sea-route-capacity-10-06 (accessed 11 June 2015).

10. These instruments are the 2012 Federal Law, supra n. 8, and Russian Federation, Rules of Navigation on the Water Area of the Northern Sea Route, dated 17 January 2013. For an introduction to these instruments, see Jan J. Solski, 'New Developments in Russian Regulation of Navigation on the Northern Sea Route', Arctic Review on Law and Politics 4, no. 1 (2013): 90-119.

11. As a result of the reorganisation of the IMO's Sub-Committees in 2013, the 57th session of the DE Sub-Committee (DE 57) was followed by the 1st session of the SDC Sub-Committee (SDC 1), instead of DE 58.

12. Accessible after registration at https://webaccounts.imo.org/.

13. The available audio records start from DE 57 in 2012 and are accessible to delegates through IMODOCS. The present author was provided access by one of the environmental NGOs with consultative status at the IMO.

14. Chairman of the working group, Development of a Mandatory Code for Ships Operating in Polar Waters: Report of the Intersessional Working Group, IMO Doc. SDC 1/3, 10 October 2013; and Norway, Ship Design and Construction: Draft Polar Code, Part I-B, IMO Doc. MSC 94/INF.4, 4 March 2014.

15. Canada, Reports of Sub-Committees: Comments on the outcome of SDC 1: Amendments to the Convention for the Prevention of Pollution from Ships, 1973, as Modified by the Protocol of 1978 Relating to Thereto (MARPOL), MEPC 66/11/7, 21 February 2014. 
16. In the case of Norway, it should be noted that part of its submissions were written as chair of a correspondence or intersessional working group entrusted with the detailed work on the Polar Code between the sessions of the Committees and Sub-Committees. The United States also submitted five proposals to Sub-Committees other than DE and SDC.

17. Jon Elster, 'Arguing and Bargaining in Two Constituent Assemblies', University of Pennsylvania fournal of Constitutional Law 2, no. 2 (2000): 372-4. For a summary of Elster's arguing and bargaining and its reformulation, see Thomas Saretzki, 'From Bargaining to Arguing, from Strategic to Communicative Action? Theoretical Distinctions and Methodological Problems in Empirical Studies of Deliberative Policy Processes', Critical Policy Studies 3, no. 2 (2009): 157-64.

18. Elster, 'Arguing and Bargaining', supra n. 17, 373-7; Saretzki, 'From Bargaining to Arguing', supra n. 17, 158; and Mark E. Warren et al., 'Deliberative Negotiation', in Negotiating Agreement in Politics, ed. Jane Mansbridge et al. (Washington DC: APSA, 2013), 93.

19. Elster, 'Arguing and Bargaining', supra n. 17, 371-2; and Saretzki, 'From Bargaining to Arguing', supra n. 17, 157-64. In the present article, the term 'bargaining' is preferred over 'negotiation', so as to differentiate between bargaining and the IMO's negotiations of the Polar Code. The latter is not intended to imply that the Polar Code process was dominated by bargaining.

20. Elster, 'Arguing and Bargaining', supra n. 17, 392; and Saretzki, 'From Bargaining to Arguing', supra n. 17, 158-9.

21. Jon Elster, 'Introduction', in Deliberative Democracy, ed. Jon Elster (Cambridge: Cambridge University Press, 1998), 6.

22. Ibid.

23. See table in Warren et al., 'Deliberative Negotiation', supra n. 18, 93a, and for a description of different negotiation outcomes, 94-98.

24. Jon Elster, 'Deliberation and Constitution Making', in Deliberative Democracy, ed. Jon Elster (Cambridge: Cambridge University Press, 1998), 101-4.

25. Elster, 'Arguing and Bargaining', supra n. 17, 406-14. There is also what I consider a version of strategically used arguments, legitimacy talk through indirect speech, where one disguises demands with reference to universal values, thereby giving legitimacy to one's claim. See Matthew D. Stephen, “Can You Pass the Salt?' The Legitimacy of International Institutions and Indirect Speech', European fournal of International Relations 21, no. 4 (2015): 768-92.

26. Elster, 'Arguing and Bargaining', supra n. 17, 414-8.

27. Jane Mansbridge et al., 'Norms of Deliberation: An Inductive Study', fournal of Public Deliberation 2, no. 1 (2006): 2-5; and Mark E. Warren et al., 'Deliberative Negotiation', supra n. 18, 94.

28. United Nations Convention on the Law of the Sea, Montego Bay, 10 December 1982. See also, Aldo Chircop, 'The International Maritime Organization', in The Oxford Handbook of the Law of the Sea, ed. Donald R. Rothwell et al. (Oxford: Oxford University Press, 2015), 429-31.

29. Convention on the International Maritime Organization, Geneva, 6 March 1948.

30. Ibid., art. 2 (b).

31. In the Arctic setting, the Arctic Council's Arctic Marine Shipping Assessment 2009 Report recommended support for the IMO's efforts in harmonising international standards relating to ship operations in the Arctic.

32. Tore Henriksen, 'The Polar Code: Ships in Cold Water-Arctic Issues Examined', CMI Yearbook 2014 (2014): 344.

33. Convention on the IMO, supra n. 29, art. 1 (a).

34. IMO, Strategic Plan for the Organization (2013-2017), Assembly Res. A.1037(27), 22 November 2011, Annex 1. 
35. Denmark, Norway and the United States, Work Programme: Mandatory Application of the Polar Guidelines, IMO Doc. MSC 86/23/9, 24 February 2009, 4; and Denmark, Norway and the United States, Work Programme of the Committee and Subsidiary Bodies: Mandatory Application of the Polar Guidelines, IMO Doc. MEPC 59/20/1, 6 April 2009, 4.

36. IMO Res. MSC.385(94) and MEPC.264(68), supra n. 1, Introduction 1.

37. A similar approach was suggested by Bai when discussing the underlying principles of the Polar Code. She identifies the principles of non-discrimination, which can be linked to the equal application of uniform standards, and safety of life at sea and pollution prevention as 'substantive principles of Arctic shipping governance'. Jiayu Bai, 'The IMO Polar Code: The Emerging Rules of Arctic Shipping Governance', The International fournal of Marine and Coastal Law 30, no. 4 (2015): 680.

38. See, for example, Heather A. Conley and Caroline Rohloff, 'The New Ice Curtain: Russia's Strategic Reach to the Arctic', Report of the CSIS Europe Program, 2015; Laruelle, Russia's Arctic Strategies, supra n. 5.

39. Article 234 provides coastal States with the 'right to adopt and enforce non-discriminatory laws and regulations for the prevention, reduction and control of marine pollution from vessels in ice-covered areas within the limits of the exclusive economic zone'. For a discussion on the international legal basis of the NSR regime, see Solski, 'New Developments', supra n. 10, 94-103; and Albert Buixadé Farré et al., 'Commercial Arctic shipping through the Northeast Passage: Routes, Resources, Governance, Technology, and Infrastructure', Polar Geography 37, no. 4 (2014): 309-11.

40. Andrea Scassola, 'An International Polar Code of Navigation: Consequences and Opportunities for the Arctic', The Yearbook of Polar Law V (2013): 286-7. See also the concerns raised by several delegations during the Polar Code negotiations, IMO, Report to the Maritime Safety Committee, Doc. DE 55/22, 15 April 2011, para. 12.7.

41. Buixadé Farré et al., 'Commercial Arctic shipping', supra n. 39, 313-6; and Arild Moe, 'The Northern Sea Route: Smooth Sailing Ahead?' Strategic Analysis 38, no. 6 (2014): 794-7.

42. Conley and Rohloff, 'The New Ice Curtain', supra n. 38, 62-4; and Laruelle, Russia's Arctic Strategies, supra n. 5, 158.

43. While Russia is not among the biggest flag States, there have been plans to boost the presence of Russian-flagged vessels in the Russian Arctic, see Atle Staalesen, 'Russian Arctic for Russian ships', Barents Observer, 19 June 2015, http://barentsobserver.com/en/energy/ 2015/06/russian-arctic-russian-ships-19-06 (accessed 22 June 2015).

44. The Polar Operational Limit Assessment Risk Indexing System (POLARIS) is a system for determining operational limitations in ice conditions, developed by the International Association of Classification Societies (IACS), see IACS, Consideration and Adoption of Amendments to Mandatory Instruments: POLARIS — Proposed System for Determining Operational Limitations in Ice, IMO Doc. MSC 94/3/7, 12 September 2014.

45. Russian Federation, Development of a Mandatory Code for Ships Operating in Polar Waters: Procedure of Accounting for National Regulations, IMO Doc. DE 55/12/23, 1 February 2011; and Russian Federation, Development of a Mandatory Code for Ships Operating in Polar Waters: $A$ Proposal to Appoint Categories Depending on the Ice Reinforcement of Ships, IMO Doc. DE 56/10/14, 24 December 2011.

46. DE 55/12/23, supra n. 45, with reference to Canada, Development of a Mandatory Code for Ship Operating in Polar Waters: Proposed Framework for the Code for Ships Operating in Polar Waters, IMO Doc. DE 53/18/2, 20 November 2009, 2.

47. Ibid.

48. DE 56/10/14, supra n. 45, 1.

49. The United States registered its concerns with regard to the legal basis and safety aspects of Canadian and Russian regulations and was supported by other delegations in its doubts over the use of LOSC art. 234 by these two States, as well as with regard to the possibility that 
'the Polar Code in itself would provide the international legal basis for these systems'. See DE 55/22, supra n. 40.

50. IMO, Report to the Maritime Safety Committee, Doc. DE 56/25, 28 February 2012, para. 10.15 .

51. MEPC 66/11/7, supra n. 15 .

52. While the intention of art. 234 is to enhance the protection of the marine environment through more stringent coastal State legislation, it has been questioned whether some elements of the Russian and Canadian legislation could fit in the scope of art. 234, notably mandatory reporting and authorization to enter certain waters. It has also been highlighted that Canada and Russia might interpret art. 234 as providing the right to maintain legislation that is less stringent than international standards.

53. DE 55/12/23, supra n. 45, 2.

54. Ibid.

55. DE 56/10/14, supra n. 45, 1.

56. DE 56/25, supra n. 50, Annexes 21 and 22.

57. Russian Federation, Development of a Mandatory Code for Ships Operating in Polar Waters: Proposals Related to an Environmental Chapter of a Mandatory Code for Ships Operating in Polar Waters (Polar Code), IMO Doc. DE 57/11/12, 25 January 2013.

58. IMO, Report of the Marine Environment Protection Committee on Its Sixty-Fifth Session, Doc. MEPC 65/22, 24 May 2013, para. 11.49.

59. Russian Federation, Development of a Mandatory Code for Ships Operating in Polar Waters: Comments on Chapter 1 of Part II-A, IMO Doc. SDC 1/3/18, 29 November 2013; Russian Federation, Reports of Sub-Committees: Comments on the Outcome of SDC 1: Environmental Issues Related to the Draft Code for Ships Operating in Polar Waters (Polar Code), IMO Doc. MEPC 66/11/3, 24 January 2014; Russian Federation, Mandatory Code for Ships Operating in Polar Waters: Comments on the Environmental Matters in the Polar Code (Part II-A, Chapter 1), IMO Doc. MEPC 67/9/2, 8 August 2014; and Russian Federation, Mandatory Code for Ships Operating in Polar Waters: Comments on the Report of the Polar Code Correspondence Group (Part II-A, Chapter 1), IMO Doc. MEPC 67/9/3, 15 August 2014.

60. The Russian proposals concern discharges in the Arctic only, as discharges of oil and oily mixtures in Antarctic waters had previously been prohibited in MARPOL Annex I. Since the Polar Code is supplementary in nature and only deals with issues not already regulated by other IMO instruments, discharges of oil and oily mixtures in Antarctic waters are not touched upon in the Polar Code.

61. SDC $1 / 3 / 18$, supra $\mathrm{n} .59,1$.

62. IMO, Meeting Audio, SDC 1, 21 January 2014, 14:41:13.

63. DE 57/11/12, supra $\mathrm{n}$. 57. Russia also argued against establishing special areas for other purposes, including sewage and grey waters and heavy fuel oil, in its statement to DE 56, on grounds that proposal for special areas can only originate from Parties to MARPOL and need to be well-grounded; see DE 56/25 Annex 22, supra n. 56.

64. MEPC 66/11/3, supra n. 59, 2; MEPC 67/9/2, supra n. 59, 2; and MEPC 67/9/3, supra n. 59,2 .

65. The influence of the Polar Code on shipping and the economic activity of coastal States was also highlighted by Russia in one of its statements, which is more general in nature, see DE 56/25 Annex 21, supra n. 56.

66. Russian Federation, Mandatory Code for Ships Operating in Polar Waters: Comments on the Report of the Polar Code Correspondence Group (Part II-A, Chapter 1), IMO Doc. MEPC 67/9/4, 15 August 2014.

67. Kiribati et al., Development of a Mandatory Code for Ships Operating in Polar Waters: Reception Facilities for Oil and Oily Mixtures, IMO Doc. SDC 1/3/1, 11 October 2013.

68. IMO, Meeting Audio, SDC 1, 21 January 2014, 15:26:44. 


\section{Bognar}

69. Russian Federation, Development of a Mandatory Code for Ships Operating in Polar Waters: Comments on Document DE 54/13/4, IMO Doc. DE 54/13/10, 31 August 2010.

70. DE 55/22, supra n. 40, para. 12.25.

71. In addition, icebreaker escorts are mentioned in DE 56/10/14, supra n. 45.

72. DE 55/22, supra n. 40 , para. 12.25 .

73. DE 54/13/10, supra n. 69, 3.

74. IMO, Guidelines for Ships Operating in Arctic Ice-Covered Waters, MSC/Circ.1056/MEPC/ Circ.399, 23 December 2002; and IMO, Guidelines for Ships Operating in Polar Waters, Assembly Res. A.1024(26), 2 December 2009.

75. IMO, Report to the Maritime Safety Committee, Doc. SDC 1/26, 11 February 2014, Annex 10.

76. Russian Federation, Ship Design and Construction: Development of a Mandatory Code for Ships Operating in Polar Waters: The Delineation of Boundaries of the Polar Code's Scope of Application, IMO Doc. MSC 93/10/9, 25 March 2014; and IMO, Report of the Maritime Safety Committee on Its Ninety-Third Session, Doc. MSC 93/22, 30 May 2014, para. 10.26.

77. MSC 93/10/9, supra n. 76, 2.

78. Ibid., 1.

79. Ibid., 2.

80. DE 55/22, supra n. 40, para. 12.7.1.

81. For example, Chapter 3 of MARPOL Annex I contains requirements on the discharge of oil from machinery spaces of all ships. In accordance with the definitions contained in MARPOL, what is meant by 'ship' is 'a vessel of any type whatsoever operating in the marine environment', see MARPOL, supra n. 3, art. 2 (4).

82. Laruelle, Russia's Arctic Strategies, supra n. 5, 157-8.

83. MSC 93/10/9, supra n. 76, 2.

84. Russian Federation, Consideration and Adoption of Amendments to Mandatory Instruments: Polar Code: Modes of Operation in Ice and Speed Limitations, IMO Doc. MSC 94/3/21, 26 September 2014; Russian Federation, Consideration and Adoption of Amendments to Mandatory Instruments: Operational Limitations for Polar Navigation Ships, IMO Doc. MSC 94/3/22, 26 September 2014; and Russian Federation, Consideration and Adoption of Amendments to Mandatory Instruments: Draft Polar Code-Proposal for Text Improvement, IMO Doc. MSC 94/3/23, 26 September 2014.

85. MSC $94 / 3 / 22$, supra n. $84,2$.

86. Ibid., 3 .

87. A submission by the Cruise Lines International Association also points out technical problems with POLARIS, see CLIA, Consideration and Adoption of Amendments to Mandatory Instruments: Comments on Document MSC 94/3/7 (POLARIS), IMO Doc. MSC 94/3/18, 26 September 2014 .

88. See note of the Chair in MSC 93/INF.4, supra n. 14, Annex, 6.

89. Square brackets denote text on which final agreement has not yet been reached.

90. MSC 93/22, supra n. 76, para. 10.25.

91. DE 56/25, supra n. 50.

92. This number also includes the two statements Russia made at DE 56.

93. MEPC 66/11/7, supra n. 15.

94. See among others, SDC 1/26, supra n. 75, Annex 10; and MEPC 66/11/7, supra n. 15.

95. See for example, MEPC 66/11/3, supra n. 59, 2; MSC 93/10/9, supra 76, 2; MEPC 67/9/2, supra 59, 2; MEPC 67/9/3, supra 59, 2; MSC 94/3/21, supra n. 84, 3; and MSC 94/3/22, supra n. $84,3$.

96. In fact, the draft provisions on reception facilities were the only ones in the Polar Code which directly addressed coastal and port States and created obligations for them. 
97. Similar Russian behaviour is observed in the context of three separate environmental regimes examined in Anna Korppoo, Nina Tynkkynen, and Geir Hønneland, Russia and the Politics of International Environmental Regimes: Environmental Encounters or Foreign Policy? (Cheltenham: Edward Elgar, 2015).

98. This was underscored in debate when Russia urged for stimulation of the development of Arctic shipping, not prohibitive measures. IMO, Meeting Audio, SDC 1, 21 January 2014, 12:03:01. 